\title{
LOS ESTUDIOS DE LENGUA LITERARIA DE LA ESCUELA ESPAÑOLA
}

Francisco Abad

UNED

A Francisco Abad Lacrouts, que estás en los cielos

RoMANTICISMO, POSITIVISMO E IDEALISMO

Entendemos por escuela española de lingüística o de filología, en un sentido estricto de la expresión, a la formada por don Ramón Menéndez Pidal y sus discipulos directos; en sentido amplio se llama muchas veces sin más «escuela española» a los lingüistas o filólogos españoles incluso de todos los tiempos, pero en primer término el troquel ha servido para designar a la escuela pidalina.

Sucesivamente Coseriu, Antonio Badía, Lapesa, etc., han identificado la escuela española con la de Menéndez Pidal, y esto mismo hacemos nosotros, aunque por supuesto la lingüística y la filología hecha en España no se agota con ellos. La presente escuela fundamentalmente del «Centro de Estudios Históricos» ha despertado siempre no obstante incomprensiones y recelos, y en 1940 - por ejemplo- escribia de ella Ángel González Palencia: «Tan pobres andaban de publicaciones... En cambio todo eran obras magnas en preparación... El Centro creció pomposamente, y contra lo previsto por sus fundadores, no sirvió para adiestrar a los jóvenes en la investigación» (j!).

Fue idea romántica - destaca la critica - la de que todo es en función de lo que ha sido, y así el romántico logra la comprensión cuando conoce los orígenes; romántico-positivamente, Menéndez Pidal y sus discípulos atendieron a «lo que ha sido» la lengua española, y de modo específico a sus origenes. No obstante la obra pidalina y de sus discípulos ha tenido 
mayores alcances, ya que al positivismo inicial han unido su falsación parcial por medio del idealismo filológico.

El idealismo lingüístico busca encontrar las motivaciones humanas de los hechos tenidos en cuenta, y en este propósito se han movido nuestros autores; aunque a veces se diga que el idealismo supone una forma de inmanentismo, en realidad no es así, y no resulta cierta tal caracterización.

En su decisión de superar la lingüística positiva, la escuela española ha atendido a los estilos literarios, esto es, a la historia de la lengua literaria; además tampoco le fue ajena la historiografia literaria, la historia de las teorías poéticas. En una evocación de García Blanco, Lapesa ha dibujado bien el perfil de los hechos, y con ese trazo estamos nosotros de acuerdo:

\begin{abstract}
Representaba Meyer-Lübke el conocimiento de la evolución de las lenguas románicas en los procesos obedientes a las tendencias que... han ido modelando cada una. Vossler por el contrario significaba... renovación espiritualista, atención a los elementos creadores del lenguaje... García Blanco adquirió el dominio de la metodología positivista, imprescindible en toda labor lingüistica seria, y asimiló cumplidamente el impulso elevador venido de Vossler... Menéndez Pidal y su escuela del Centro de Estudios Históricos aunaban, como Vossler, el cultivo de la lingüistica con el de la historia literaria.
\end{abstract}

Tan imprescindible resulta pues la metodología positivista como junto a ella el interés por la creación lingüística, y así lo entendieron y llevaron a la práctica el maestro coruñés y sus discípulos ${ }^{1}$.

Menéndez Pidal y Amado Alonso

En particular varios de los miembros del «Centro» han trabajado en historia de la lengua literaria, a saber: el propio Menéndez Pidal, Tomás

1 Nuestro amigo querido Juan Gutiérrez Cuadrado ha llamado una vez «hagiógrafo» de Menéndez Pidal a Diego Catalán, pero en verdad este autor ha coincidido o no con don Ramón según los hechos científicos le llevaban a ello.

Esperamos por otra parte que a nosotros mismos tampoco se nos pueda llamar en justicia hagiógrafos de la escuela del Centro de Estudios Históricos; si bien moral y vivencialmente nos identificamos con esta tradición de la cultura española contemporánea, en los aspectos técnicos asimismo hemos coincidido o no con ella. Para nosotros constituye un deber de conciencia profesional, inventariar y comentar la aportación de la Junta para Ampliación de Estudios al patrimonio de nuestro pasado. 
Navarro Tomás, Amado Alonso (con su discípula María Rosa Lida), Salvador Fernández Ramírez, Dámaso Alonso, Rafael Lapesa..., y a estos nombres se puede añadir también el de García Blanco.

Aunque la obra de Menéndez Pidal resulta bibliográficamente compleja, y algunos escritos suyos están publicados por separado y además en el todo conjunto del que forman parte, puede decirse que conocemos de don Ramón unas diez monografias que tratan de cuestiones de historia de la lengua literaria española, alguna de ellas con dimensiones de verdadero libro. Al margen de la abreviatura general que suponen los prologuillos y las notas de la Antología de prosistas castellanos (aumentada con los autores medievales a partir de la segunda edición, y llamada también luego Antología de prosistas españoles), contamos con escritos sobre don Juan Manuel y Juan Ruiz, sobre el Cuatrocientos, el Quinientos en general, Santa Teresa, Lope, el culteranismo, y la lengua del Seiscientos; además don Ramón trató del estilo de la épica castellana y del Cantar del Mio Cid, de la lengua literaria del romancero, etc.

En total existen más páginas pidalinas publicadas respecto al idioma poético, de las que parecen ser recordadas o incluso conocidas; varias exposiciones de conjunto presentan este hueco visible, y nuestra experiencia nos dice que lo mismo ocurre en las oposiciones universitarias. Asistimos en estos años a una tendencia a considerar a don Ramón «el neogramático español», y a acentuar su filología positivista, pero ello quizá no sea sino una parte de la verdad. Incluso un estudio específico como el de Hans Helmut Christmann (Filología idealista y lingüística moderna), proclama que sería improcedente contar a Menéndez Pidal en la orientación idealista, lo que con una argumentación detallada no creemos pueda decirse ${ }^{2}$.

Amado Alonso ha sido siempre unánimemente recordado y alabado, pero acaso más en juicios de valor que tras un análisis de sus trabajos. En 1942 publicaba Amado en un solo volumen su «Ensayo sobre la novela histórica» más el otro escrito «El modernismo en "La gloria de don Ramiro"»; este tomo sin embargo parece haber quedado un poco en olvido, y sin embargo resulta muestra de relieve de cómo la escuela española atendió al idioma literario y a (la historia de) las doctrinas poéticas.

Alonso concibe los géneros literarios no sólo como formas naturales (diríamos hoy) del discurso artístico, sino en tanto entidades temporales compuestas por un conjunto de rasgos propios; se está refiriendo a la novela histórica ochocentista, y dice así:

${ }^{2}$ Los razonamientos pidalinos resultan a veces contradichos pero no contraargumentados; se habla así a la letra de la dialectización experimentada por los manuscritos del Libro de Alexandre, pero sin detallar las pruebas presuntas que invaliden las de don Ramón al postular el leonesismo original del poema. 
Aparte las caracteristicas individuales de cada novela, es notorio que el romanticismo y el postromanticismo han venido cultivando un tipo de relato imaginativo de apariencia histórica con determinaciones y propósitos estéticos que forman tradición, desarrollados o rectificados al pasar de mano en mano; esto ha hecho que la novela histórica como tal haya ido adquiriendo sus líneas formales propias, y que con eso se nos ofrezca como un género o subgénero literario considerado aquí como históricamente condicionado, no como miembro de una construcción sistemático-retórica de géneros literarios.

Amado considera que Manzoni «representa un capítulo importante en la historia de las teorías poéticas", y en lo que atañe a su Ensayo le dedica páginas amplias. Recoge su idea de que la novela histórica no vale como historia, ni vale tampoco en cuanto narración que produzca asentimiento homogéneo, ya que sus materiales son heterogéneos; Amado Alonso glosa con palabras propias al novelista e ilustra luego la tradición aristotélica de sus ideas, y concluye que «Muzio,... Sperone Speroni, Antonio Riccoboni, Ludovico Castelvetro, Leonardo Salviati..., van afirmando, cada cual a su modo, que el poeta no puede ocuparse de temas históricos sin dejar de ser poeta".

No obstante - añade nuestro autor por su parte, de acuerdo también con Alessandro Piccolomini-, ningún razonamiento ni incluso el de Manzoni "puede hacernos renunciar a nuestra evidencia de que la poesía no se deja anular porque tome su materia de entre las cosas realmente sucedidas". Vemos pues a Amado Alonso hacer, en las páginas del Ensayo sobre la novela..., tanto historia de la teoría poética cuanto teoría literaria propiamente dicha. Otras páginas de Menéndez Pidal, de Dámaso Alonso, etc., están dedicadas asimismo a la historiografia (y a la teorización) literarias.

El estilo en prosa de Enrique Larreta igualmente queda analizado por nuestro autor en el segundo de los estudios de su libro. La gloria de don Ramiro nos dice que está escrita con prosa modernista, y que por modernista es impresionista: así en la novela «la luz ambiental, el rayo de sol o de luna, los reflejos, destellos, relumbres, rubores y transparencias, son con mucha frecuencia los auténticos protagonistas del momento».

En unas líneas de la novela destaca el filólogo navarro la «especial fuerza expresiva» de «la acumulación de silabas terminadas en resonantes nasales»; se trata de cuanto Larreta escribe: «El sol acababa de ocultarse, y blanda, lentamente, las parroquias tocaban las oraciones. Era un coro, un llanto continuo de campanas cantantes, de campanas gemebundas en el tranquilo crepúsculo». Comentando elocutivamente otro pasaje (I, 26), explica: «La expresión de exacerbamiento sonoro está favorecida por la feliz imagen del «túmulo de silencio y de luto» derrumbado con estruendo...; véase la granizada de palabras que indican violencia y frenesí sonoros: descolgarse, trueno, alarido, turbión resoplante, estallar, repique acelerado. Varias imá- 
genes - derrumbe, descolgarse, turbión- cooperan para infundir en la sensación de sonoridad la ilusión de movimiento incontenible».

Además Amado Alonso advierte en La gloria de don Ramiro la descripción por medio de oraciones nominales, así como arcaísmos sintácticos; se cuenta con sintaxis arcaizante (explica) lo que los personajes hacen, y con sintaxis moderna lo que se siente.

Lengua y teoría literarias entran en el presente volumen de Amado Alonso, tomo - como decimos- valioso por sí mismo, y representativo de una de las varias direcciones en que ha trabajado la escuela filológica española.

GEOGRAFIA LINGUUISTICA Y ESTILISTICA

A Salvador Fernández Ramírez tampoco le fue ajeno el interés por el idioma literario, lo que se prueba tanto por algunos escritos especificos como por observaciones y materiales incluidos en su tratado gramatical. Basta iniciar la lectura del mismo para encontrarnos con «las que podemos llamar grafias convencionales», con las cuales «se transcriben literariamente los sonidos y ruidos inarticulados que el hombre produce, como la risa, el llanto, etc.); pocas líneas más adelante dedica don Salvador su $\$ 61$ a la "Perseverancia en el sonido", y estampa un claro razonamiento estilístico: «La insistencia o perseverancia en el sonido obtenido por la repetición de una palabra o de un grupo de palabras - dice-, atiende en general a los momentos expresivos, emocionales y voluntativos del lenguaje». Esta observación lá ejemplifica, entre otros textos, con uno muy nítido del Cántico guilleniano.

Por otra parte la estilistica de Dámaso Alonso parece ser un tema relativamente estudiado; no obstante, quedan acaso cosas fundamentales por decir y textos suyos que no deben ser preteridos a este respecto, entre ellos el de 1941 «Sobre la enseñanza de la filología española».

Don Dámaso advierte entonces el entronque positivo de la geografia lingüística, pero a la vez subraya cómo la doctrina de Menéndez Pidal «concilia en una fórmula superior la noción de la ley fonética y de la historia particular de cada palabra", lo que implícitamente quiere decir -interpretamos nosotros - que no todo en la geografia lingüística era positivismo.

Una falsación en efecto del positivismo viene de la parte de la geografia lingüística, y la escuela española contribuyó a ella con la demostración de lo que hay de historia particular en las palabras. También falsaba la escuela española el positivismo con su atención a lo estilístico, que -según este escrito de Dámaso Alonso- consiste en lo expresivo, sea intelectual o afectivo, y ello tanto en las «lenguas» (común, literaria) como en las «hablas». 
«Para mí estilística - dice a la letra don Dámaso- es el estudio de todo lo que es expresivo, lo mismo en el lenguaje artístico que en el usual... Lo afectivo y lo intelectivo no pueden separarse;... lo intelectual deja su huella expresiva lo mismo que lo afectivon.

Con gracia de creador literario, nuestro autor manifiesta en definitiva cómo la construcción neogramática era "una jaula sin pájaro», aunque de lo que se trata no es de arruinar tal construcción, sino de «hacer entrar al pájaro en la jaula». En efecto Vossler y en parte la geografía lingüística suponen frente al positivismo lingüístico, lo mismo que Dilthey respecto a la psicología y en general respecto a las «ciencias del espíritu», etc.

\section{RAFAEL LAPESA}

Otro discipulo directo de Menéndez Pidal que siempre ha hecho suyos los estudios estilísticos es Rafael Lapesa; Lapesa ha dado a luz en estos últimos años análisis rigurosos, como los de «El lenguaje literario en los años de Larra y Espronceda» y los de «Algunas consideraciones sobre el léxico político en los años de Larra y Espronceda», y además ha tratado del estilo elocutivo de Santa Teresa, Calderón o Jorge Guillén, en artículos que ahora se hallan en su libro De Ayala a Ayala.

Este De Ayala a Ayala es volumen que asimismo incorpora testimonios autobiográficos y vivenciales de su autor, que un estudioso o un enamorado del «Centro de Estudios Históricos» no puede leer sin emoción; Lapesa sabe además guardar siempre equilibrio entre el ánimo de concordia y de sana convivencia por una parte, y el reconocimiento de lo real que a veces muestra su complejidad y su dureza por otra, por lo que su testimonio resulta ponderado y sereno, aquí y en otras páginas. Refiriéndose por ejemplo a su participación en el Congreso calderoniano del C.S.I.C., dice a la letra nuestro autor: "Acepté sin embargo... por considerar que, aun siendo bien conocida mi absoluta desvinculación respecto a la entidad organizadora, no debía negarle el pan y la sal».

Justamente el trabajo sobre don Pedro, «Lenguaje y estilo de Calderón», resulta acaso el más denso y excepcional de todo el libro; en las páginas dedicadas a Guillén, Lapesa trata de vincular sus usos elocutivos con su imagen del mundo, y de esta manera establece:

La abstención de actualizadores tiene en la mayoría de los casos una finalidad clara: desvincular a los sustantivos de toda referencia concreta para sacar a la luz lo poéticamente esencial que hay en las realidades. Es hazaña mil veces repetida a lo largo de la obra guilleniana: cuando el vuelo y el piar de las 
aves invaden la atmósfera, "Todo en el aire es pájaro" y el espacio queda "henchido de presenciar.

Establecer las mismas relaciones entre lenguaje y sustancia de pensamiento, es lo que también había hecho Lapesa en su día respecto por ejemplo de Góngora.

FINAL

La escuela filológica española hizo suya en general la construcción del positivismo neogramático, pero a la vez falsó este positivismo mediante tanto la geografia lingüística como los estudios estilísticos. La lengua literaria (y también a veces la historia de las doctrinas poéticas) no escapó a su interés y a su atención, y sobre ellas escribieron monografias y artículos que los especialistas no deben dejar de tener en cuenta, para confirmar tales trabajos, para prolongarlos o para corregirlos.

En esta segunda mitad de nuestra centuria los estudios sobre lengua literaria o sobre la lengua de los textos literarios, viene siendo asimismo proseguida por distintos profesionales: Fernando Lázaro, Ricardo Senabre, Carmen Bobes, José Manuel González Calvo, Manuel Alvar, Manuel Ariza, y otros tantos.

${ }^{2}$ Los razonamientos pidalinos resultan a veces contradichos pero no contraargumentados; se habla asi a la letra de la dialectización experimentada por los manuscritos del Libro de Alexandre, pero sin detallar las pruebas presuntas que invaliden las de don Ramón al postular el leonesismo original del poema. 